\title{
Mitochondrial DNA Variation and Population Genetic Structure of Mud Crab, Scylla serrata from Pakistan/Northern Arabian
}

\section{Sea}

\author{
Noor Us Saher ${ }^{1, *}$ (D) Farah $\mathrm{Naz}^{1}$, Mustafa Kamal ${ }^{2}$ \\ ${ }^{1}$ Centre of Excellence in Marine Biology University of Karachi, Karachi 75270, Pakistan \\ ${ }^{2}$ Department of Biotechnology University of Karachi, Karachi 75270, Pakistan
}

\section{Article History}

Received 26 July 2019

Accepted 23 December 2019

First Online 25 December 2019

\section{Corresponding Author \\ Tel.: +922199261551 \\ E-mail: noorusaher@yahoo.com}

\section{Keywords}

16S rRNA

$\mathrm{COI}$

Genetic structure

IWP

Mud crab

\begin{abstract}
Amongst the 50 largest Marine Ecosystems (LMEs) that yield $95 \%$ of the annual marine fishery revenues throughout the world, the Arabian Sea ranked 32 on a global measure. Scylla serrata is an important resource of the aquaculture and commercial fishery in the Northern Arabian Sea (NAS). The mt-DNA variations in S. serrata (n16) were estimated from the two populations: Sandspit back waters (n8) and Korangi creek mangrove areas (n8) Pakistan. The study based on 16S rRNA and Cytochrome Oxidase (COI) genes, high haplotype and low nucleotide diversity was observed in the populations of $S$. serrata. The neutrality tests (Tajima's and Fu's F's) were nonsignificant, whereas mismatch analysis revealed the potential population expansion event occurred in the (NAS). Furthermore, we conducted a phylogeography analysis of S. serrata based on the COI obtained from GenBank ( $n 47)$ determined from specimens of the IWP. Out of all sequences n63 (16 from Pakistan and 47 from Genbank), 46 different $\mathrm{COI}$ haplotypes were identified. The AMOVA indicated the phylogeographic regional partition and genetic structure in IWP. In the present study, the partial sequences of the genes provide orientation with the valuation of the genetic structure, phylogeography and genetic affiliation of S. serrata in the IWP region.
\end{abstract}

\section{Introduction}

Marine species are proficient for extensive dispersal potential due to planktonic phase or various stages of their life cycle that predicted to strong genetic connectivity throughout their extension range and therefore; expected for an island model of migration (Palumbi, 1994). According to Hellberg (1996); positive correlation between the duration of a planktonic larval phase and levels of gene flow have been shown for a wide range of marine species and estimates that planktonic dispersal endorses genetic and demographic connectivity among populations (Scheltema, 1971, Crisp, 1978, Nanninga and Manica, 2018). Accessibility of marine populations due to numerous nonrandom factors and genetic adaptation in the marine environment may, occur through ecological and geographic limitations such as dispersal capability, niche portioning and/or local adaptation (Hedgecock, 1986; Féral, 2002). Population genetics offer a useful advancement in management of marine systems as a relationship among the dispersive ability of organisms and the genetic differentiation of populations as provide a fundamental link between ecology and evolution (Ayre and Hughes, 2000) and genetic relatedness represent a proxy to the extent of recruitment that is occurring between two areas.

DNA analysis has become the most recent and reliable solution for systematic, population genetics and phylogenetic studies. In principal, the mitochondrial DNA (mt-DNA) has been one of the most widely used molecular markers of taxonomic and phylogenetic 
studies in animals (Avise et al., 2004; Shekhar et al., 2011). S. serrata has distinct distribution throughout the Indo West Pacific region as ranged from Tahiti, Australia including the Philippines, Indonesia, Japan, East and South Africa and to the Red Sea (Sakai, 1976; Dai and Yang, 1991). It assumed that high levels of gene flow occur in populations of $S$. serrata and it depends on life history and dispersion pattern (Gopurenko, 2002). Female $S$. serrata releases eggs in offshore waters, thereby facilitating the high levels of oceanic dispersal and mixing of propagules before re-entry into estuarine adult habitats (Hill, 1994).

Genus Scylla having high commercial and economic significance in catch contribution of tropical and sub-tropical region and also a source of the aquaculture and marketing fishery enterprises (Cristensen et al., 2004). Previously single species recognized in the genus Scylla, the review of detailed previous work illustrates that genus Scylla includes more than one species (Estampador, 1949a, b; Serene, 1952; Stephenson and Campbell, 1960; Ong, 1964; Joel and Raj, 1980; Radhakrishnan and Samuel, 1982; Fushimi, 1983; Oshiro, 1988; Kathirval and Srinivasagam, 1992; Fuseya and Watanabe, 1995; Fuseya and Watanabe, 1996; Watanabe and Fuseya, 1997; Fuseya, 1998). Keenan et al., (1998) identified genus Scylla as a four distinct species $S$. serrata, S. tranquebarica, S. olivacea and S. paramamosain based on the morphological and molecular approaches. Currently, Ma et al., (2012) confirmed the work of Keenan et al., (1998) through DNA bar-coding technique and confirmed all the four species: S. tranquebarica, S. olivacea, S. paramamosain and S. serrata from China. After the revision of Keenan et al., (1998), Kazmi et al., (2000) revised the taxonomy of the species within the genus Scylla and confirmed the presence of two species of Genus Scylla: S. serrata, $S$. tranquebarica from the coastal waters of Pakistan. According to Avise, (1989) and Brophy, (2004) the accurate taxonomic identification is important to the growth of management strategies and breeding program for sustainable fisheries resource. Sometimes, the external morphology remain insufficient for taxonomic and homogeneous chronological structures and leads to difficulty in the establishment of phylogenetic relationships (Stiassny, 1993; Thomson et al., 1997). Taxonomic and molecular exploration in description of sister species has revealed entire species complexes, including economically important species (Matsuoka and Hatanaka, 1991 and Knowlton, 1993).

The current study not only explains the mitochondrial DNA variation of $S$. serrata from the Pakistan Northern Arabian Sea, also determine the phylogeographic structure and levels of population connectivity in the marine environment. The molecular data based on Cytochrome Oxidase COI and 16S rRNA was used to surmise the population genetic structure, genetic relatedness and evolutionary history of $S$. serrata population in the Indo-West Pacific region by using genetic methods (nucleotide diversity tests, network analysis, mismatch analysis and AMOVA). Although features concerning the life history of $S$. serrata and its distribution in the IWP that makes it model for examining hypotheses of genetic structure specific to other marine species.

\section{Materials and Methods}

\section{Samples Collection and Morphological Examination}

The crabs $(n=16)$ were collected from the field by direct hand pick, purchase fresh catch by local fisherman from the two populations: Sandspit back waters $(n=8)$ and Korangi creek mangrove areas $(n=8)$ from the coastal waters of Pakistan (Figure 1). Capture or purchased live crabs, immediately stored in the icebox, killed by freezing and transferred to the laboratory. The specimen identified up to the possible species level based on morphological characteristics (Fuseya and Wetanabe, 1996; Keenan et al., 1998; Kazmi et al., 2000; Jirapunpipat et al., 2008).

\section{DNA extraction and PCR amplification}

Total genomic DNA was isolated from muscle tissue (approximately $>25$ ) in the chelipeds of fresh crabs using Qiagens DNeasy Blood and Tissue Kit, following the manufacturer's instruction with some modifications of the original protocol to improve the yield and quality of the DNA extraction.

PCR technique was used to amplify the 16S rRNA and COI mt-DNA genes. Selective amplification of a 550600 base pair product from the 16S rRNA (ribosomal regions of mt-DNA) and approximately 700 base pair product from the $\mathrm{COI}$ was carried out through selected primers. Primers used to amplify the $16 \mathrm{~S}$ fragment and COI were: $\left.3^{\prime}\right)$;

16Sar (Forward) (5'-CGCCTGTTTATCAAA AACAT-

16Sbr (Reverse) (5'-CCGGTCTGAACTCAGATCACG T-3') (Palumbi et al., 1991; Schubert et al., 2000b). COI a (Forward) (5'-AGTATAAGCGTCTGGGTAGTC $\left.3^{\prime}\right)$;

COIf-L

(Revers)

$\left(5^{\prime}-\right.$ CCTGCAgGAgGAgGAgGAGAYCC - $3^{\prime}$ ) (Palumbi et al., 1991; Lai et al., 2010).

Polymerase chain reactions (PCR) condition was used according to Mantelatto et al., (2009), Schubert et al., (2006), Fratini et al., (2005) and Lai et al., (2010). In detail each PCR reaction was performed in $50 \mu \mathrm{L}$ volumes containing $15 \mu \mathrm{L}$ of DNA template (150 ng), 25 $\mu \mathrm{L}$ Go Taq Green Master Mix 2X (Promega, Madison, WI, USA), and $5 \mu \mathrm{L}$ each of forward and reverse primers (10 $\mathrm{pmol} / \mu \mathrm{L})$. PCR amplification performed in an Applied Biosystems 2720 thermal cycler. The thermal cycling program was different for both gene amplification as for the 16S rRNA amplification the following steps performed; initial denaturation cycle for $10 \mathrm{~min}$. at $95^{\circ} \mathrm{C}$, 40 cycles of $1 \mathrm{~min}$. at $95^{\circ} \mathrm{C}, 1 \mathrm{~min}$. at $46^{\circ} \mathrm{C}$ and $2 \mathrm{~min}$. at 
$72^{\circ} \mathrm{C}$ and $72^{\circ} \mathrm{C}$ for $10 \mathrm{~min}$ for final extension. Whereas, for amplification of $\mathrm{COI}$ the following steps performed during in thermal cycling profile, initial denaturation cycle for $2 \mathrm{~min}$ at $94^{\circ} \mathrm{C}$, followed by 40 cycles of $1 \mathrm{~min}$ at $94^{\circ} \mathrm{C}, 1 \mathrm{~min}$ at $50^{\circ} \mathrm{C}$ and $1.5 \mathrm{~min}$ at $72^{\circ} \mathrm{C}$, with the final extension of $72^{\circ} \mathrm{C}$ for $10 \mathrm{~min}$.

\section{Sequencing of COI mt-DNA}

All PCR products were checked for confirmation and estimation of the base pair of the amplified products amplification through the agarose gel electrophoresis. The each $5 \mu$ Lof PCR products were checked through $1 \%$ of agarose gel by horizontal gel electrophoresis in 80 volts of electric current and also compare with a Gene Ruler 100 bp Plus DNA ladder (Promega, Madison, USA \# SM0321). PCR products purified and sequenced from Macrogen Company, (Korea).

\section{Data analysis}

The DNA sequence data analyze through Applied Biosystems sequence Scanner v1.0 software. 2.2.4. Species identification and confirmation based on 97 $100 \%$ homology, assigned to the similar sequence of the same species associated through the best hit (up to high bit score) NCBI, BLASTn 2.2.26 (Zhang et al., 2000). Furthermore, the procured coding sequences submitted to the NCBI nucleotide-sequence databases through Barcode submission tools.

Before submission, the procured Cytochrome oxidase (COI) mitochondrial DNA sequences cleaned through CDS annotation than translated into protein. Open Reading Frame finder (ORF finder) used (NCBI link) to translate DNA sequences into protein and as well as for the trimming of a nucleotide sequence. The most suitable open reading frames (ORFs) were selected with its protein translation and nucleotide sequences and also verify the predicted protein by using the Smart Blast and regular Blast $P$.

Intraspecific genetic variability estimated through $16 \mathrm{~S}$ and $\mathrm{CO}$ gene sequences in S. serrata. Sequences (16S rRNA and COI) were analyzed to evaluate the evolutionary model (nucleotide and amino acid substitutions). The later evolutionary divergence analyses were estimated based on the selected evolutionary model. For the overall population, software DNA SP version 5.10 (Librado and Rozas, 2009) was employed to calculate haplotype diversity (hd) and nucleotide diversity (ріл) according to Nei (1987). Neutrality tests Ewens-Watterson (Ewens, 1972;

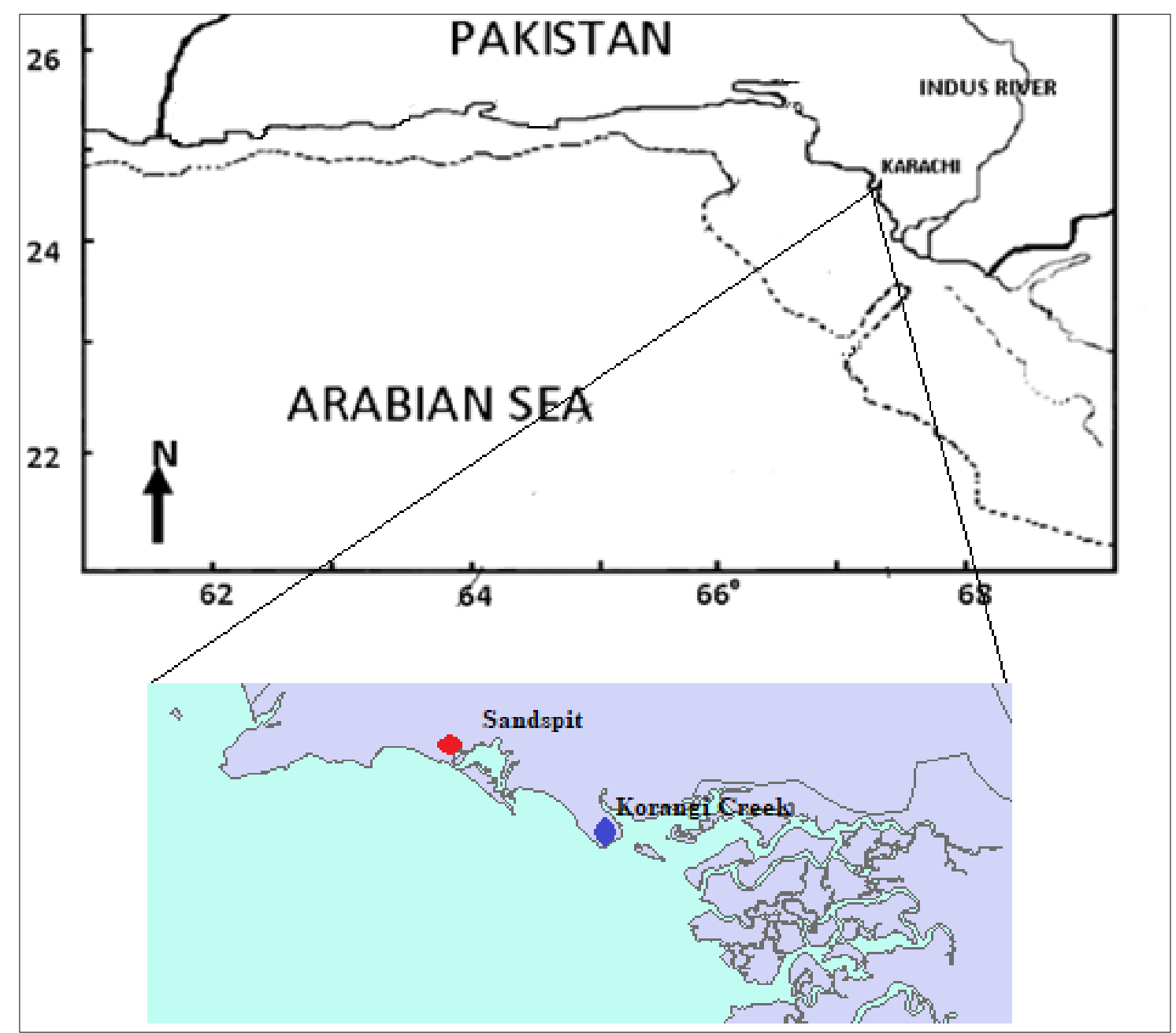

Figure 1. Map of the stud area from the coastal waters of Pakistan northern Arabia Sea 
Watterson, 1978; Chakraborty, 1990) including Tajima D (Tajima, 1989), and Fu's Fs (Fu, 1997) performed. Arlequin v. 3.1 (Excoffier et al., 2005) used for the AMOVA, mismatch distribution, Tajima's D, and Fu's Fs test of neutrality.

Furthermore, the new procured mitochondrial $\mathrm{COI}$ gene data $(n=9)$ along with data $(n=54)$ from 24 locations (Table 1) in the IWP obtained from Genbank as described by He et al., (2011) included in the current study for the phylogenetic analysis. All sequences were ATG transformed aligned in CLUSTAL W (Thompson et al., 1997). The Maximum Likelihood evolutionary model $(\mathrm{T} 92+\mathrm{G})$ were determined using MEGA 7. A medianjoining (MJ) network (Bandelt et al., 1999) of phylogenetic relationships among haplotypes was used to clarify the evolutionary relationship of $S$. serrata constructed by using software Network version 4.51 (version 4.5.1.0; Fluxus engineering, 2008) (Polzin and Daneshmand, 2003).

All currently available molecular data to infer the genetic structure, genetic relatedness and evolutionary history of S. serrata in the Indo-West Pacific region by using nucleotide diversity tests, network analysis, mismatch analysis and AMOVA.

\section{Results}

\section{General findings}

The crabs $(n=16)$ were collected from two populations Sandspit back water areas $(n=8)$ and Korangi mangrove creek areas $(n=8)$ by direct hand pick or purchase fresh catch from local fisherman. After amplification, $16 \mathrm{~S}$ and $\mathrm{CO}$ gene exhibit a band presence of UV light, whereas 100 base pair plus DNA ladder Gene Ruler used for the comparison. Sequence similarity searched by using the Basic Local Alignment Search Tool (BLAST), species homology based on at least a 99-100\% homology. DNA sequences submitted to GenBank and the accession number received for each isolate (Table 2). The BLAST search showed high sequence similarity (97-100\%) to S. serrata sequences in GenBank, indicated that misidentification of species does not occur in this study.

Table 1. Sample size, Clade, haplotypes and GenBank accession numbers in geographic distribution range of Scylla serrata

\begin{tabular}{|c|c|c|c|c|c|c|c|c|c|c|c|}
\hline $\begin{array}{l}\text { Sequence } \\
\text { No }\end{array}$ & Clade & Hap & $\begin{array}{c}\text { Accession } \\
\text { no }\end{array}$ & $\begin{array}{c}\text { Sequence } \\
\text { No }\end{array}$ & Clade & Hap & $\begin{array}{c}\text { Accession } \\
\text { no }\end{array}$ & $\begin{array}{c}\text { Sequence } \\
\text { No }\end{array}$ & Hap & Clade & $\begin{array}{c}\text { Accession } \\
\text { no }\end{array}$ \\
\hline 1 & IC & 1 & AF097003 & 24 & & 20 & AY373349 & 47 & 32 & II & AF279318 \\
\hline 2 & & 2 & AF097007 & 25 & & 19 & AY373350 & 48 & 33 & & AF279323 \\
\hline 3 & & 3 & AY373342 & 26 & & 21 & AF097016 & 49 & 34 & & AF279330 \\
\hline 4 & & 4 & AY373344 & 27 & & 21 & AF097016 & 50 & 26 & & AF279312 \\
\hline 5 & & 3 & AF097002 & 28 & & 21 & AF097018 & 51 & 35 & & AF279311 \\
\hline 6 & & 3 & AF097006 & 29 & & 21 & AY373346 & 52 & 36 & & AF279329 \\
\hline 7 & & 5 & AF097005 & 30 & & 21 & AF097017 & 53 & 37 & & AF279324 \\
\hline 8 & & 3 & AF097004 & 31 & & 21 & AF097016 & 54 & 38 & & AF279311 \\
\hline 9 & & 6 & AY373343 & 32 & & 22 & AF097019 & 55 & 39 & III & KY290374.1 \\
\hline 10 & & 7 & AY373345 & 33 & & 23 & AY373348 & 56 & 40 & & KY290376.1 \\
\hline 11 & & 8 & AF203943 & 34 & & 17 & AF279321 & 57 & 41 & & KY290378.1 \\
\hline 12 & & 9 & AF097009 & 35 & $\mathrm{IA}$ & 24 & AF279315 & 58 & 42 & & KY290381.1 \\
\hline 13 & & 10 & AF097010 & 36 & & 25 & AF279322 & 59 & 43 & & KY428865.1 \\
\hline 14 & & 10 & AF097008 & 37 & & 26 & AF279331 & 60 & 40 & & KY587766.1 \\
\hline 15 & & 11 & AF203946 & 38 & & 27 & AF279326 & 61 & 44 & & KY587767.1 \\
\hline 16 & & 12 & AF097012 & 39 & & 28 & AF279327 & 62 & 45 & & KY587779.1 \\
\hline 17 & & 13 & AF097011 & 40 & & 26 & AF097013 & 63 & 46 & & KY587393.1 \\
\hline 18 & IB & 14 & AF203945 & 41 & & 29 & AF279313 & & & & \\
\hline 19 & & 15 & AF203947 & 42 & & 27 & AF279326 & & & & \\
\hline 20 & & 16 & AF279321 & 43 & & 30 & AF279332 & & & & \\
\hline 21 & & 17 & AF279321 & 44 & & 26 & AF279310 & & & & \\
\hline 22 & II & 18 & AF093715 & 45 & & 26 & AF279317 & & & & \\
\hline 23 & & 19 & AY373341 & 46 & & 31 & AF279328 & & & & \\
\hline
\end{tabular}

Table 2. GenBank accession numbers for $16 \mathrm{~S}$ and $\mathrm{COI}$ sequence of $S$. serrata from the coastal waters of Pakistan

\begin{tabular}{lccc}
\hline \multicolumn{1}{c}{ Portunid crabs } & $\begin{array}{c}\text { 16S rRNA } \\
\text { GenBank accession numbers }\end{array}$ & No & $\begin{array}{c}\text { COI } \\
\text { GenBank accession numbers }\end{array}$ \\
\hline Subfamily: Portununie Rafinesque, 1815 & & & \\
Genus Sylla (De Hann, 1833) & KU296942.1, KU296943.1, & 7 & KY290374.1, KY290376.1, \\
Scylla serrata (Forskal, 1775) & KY062994.1, KY062995.1, & KY290378.1, KY290381.1, \\
& KY062996.1, KY062997.1, & KY428865.1, KY587766.1, \\
& KY062998.1, & KY587767.1, KY587779.1, \\
& & KY587393.1 \\
\hline
\end{tabular}




\section{Genetic diversity}

$16 \mathrm{~S}$ and COI alignment consisted of 580bp and $697 \mathrm{bp}$ with exclusion of hyper variable regions, whereas the remaining $511 \mathrm{bp}$ of $16 \mathrm{~S}$ and $426 \mathrm{bp}$ of $\mathrm{COI}$ used for the phylogenetic analysis. Likelihood ratio test revealed the selected optimum model (The T92+G Tamura 3parameter + Gamma distribution) under the Akaike information criterion (AIC). However, the models with the lowest BIC scores were considered to describe the DNA substitution pattern the best as implemented in MEGA 7 (Kumar et al., 2016).

The number of haplotypes and their diversity for $16 \mathrm{~S}$ and COI estimated for the assessment of genetic diversity and differentiation within two different populations' of Sandspit back water areas and Korangi mangrove creek area from the coastal waters of Pakistan. In 16S rRNA four haplotypes (2 from Korangi and 2 from Sandspit) determined out of 7, haplotype diversity (hd) $(0.810 \quad \mathrm{P}<=0.0168)$, whereas the nucleotide diversity (0.01 $\mathrm{P}<=0.000$ ) (Table 3$)$. In COI five haplotypes ( 3 from Korangi and 2 from Sandspit) were determined (hd 0.873, $\mathrm{P}<=0.003$ ) from 9 sequences, whereas the nucleotide diversity was $(0.007 \mathrm{P}<=0.000)$. The maximum numbers of haplotype description likely due to the selection of morphological difference individual (morphotype) from each population.

\section{Neutrality and Mismatch Analysis}

Tajima's D (Neutrality test) was estimated for COI in S. serrate $D=-1.14965(P>0.10)$ whereas Fu's Fs $1.09284(P>0.10)$. In addition, neutrality test was also performed for the 16S rRNA gene $(D=-1.53047)$ and was non-significant $P>0.10$, whereas Fu's Fs 1.7354 (Table 4). The number of base substitutions per site from an average of overall sequence pairs, within S. serrata was also estimated. The estimated inter population distance within S. serrata was $(0.001 \pm 0.001)$ for $16 \mathrm{~S}$ and $(0.006$ \pm 0.002 ) for COI. Mismatch analysis showed the bimodal pattern in two selected regions of Northern Indian Ocean bounded on the north by Pakistan and Iran, on the west by the Gulf of Aden, Guardafui Channel and the Arabian Peninsula, on the southeast by the Laccadive Sea, on the southwest by the Somali Sea, on the east by India and relate inadequately with their similar distribution this recommend the population underwent population expansion in Northern Indian Ocean Northern Arabian Sea (Figure 2).

\section{Phylogeography of S. serrata}

Cytochrome oxidase (COI) sequence of S. serrata from Northern Arabian Sea (present study) along with sequences from four geographic regions according to He

Table 3. Summary $16 \mathrm{~S}$ rRNA and $\mathrm{COI}$ sequences, sites, Haplotypes $(\mathrm{P})$ and Haplotype diversity $(\mathrm{Hd})$ at significance level $(P<=0.000)$; nucleotide diversity $(\pi)$ at significance level Theta per site $(P<=0.000)$ by using Dna SP V5 of $16 \mathrm{~S}$ rRNA and COI

\begin{tabular}{lccccccc}
\hline & Sequence & Sites & Haplotype & hd & hd $(\mathrm{P}<=0.000)$ & $\pi$ & $\mathrm{Pi}(\mathrm{P}<=0.000)$ \\
\hline 16S rRNA & 7 & 511 & 4 & 0.810 & 0.01686 & 0.01044 & $0.000^{* * *}$ \\
COI & 9 & 426 & 5 & 0.873 & 0.00352 & 0.00743 & $0.000^{* * *}$ \\
\hline
\end{tabular}

Table 4. Tajima's $D$ and Fu's $F$ Test for $\mathrm{COI}$ and $16 \mathrm{~S}$ rRNA mitochondrial DNA from the coastal waters of Pakistan

\begin{tabular}{|c|c|c|c|c|c|c|}
\hline \multirow{2}{*}{ Neutrality test } & \multicolumn{3}{|c|}{$\mathrm{COI}$} & \multicolumn{3}{|c|}{$16 \mathrm{~S}$} \\
\hline & Tajima's D & Fu's Lis D & Fu's Lis $\mathrm{F}$ & Tajima's D & Fu's Lis D & Fu's Lis F \\
\hline S. serrata & -1.14695 & -1.09284 & -1.23922 & -1.53047 & -1.58858 & -1.73574 \\
\hline
\end{tabular}

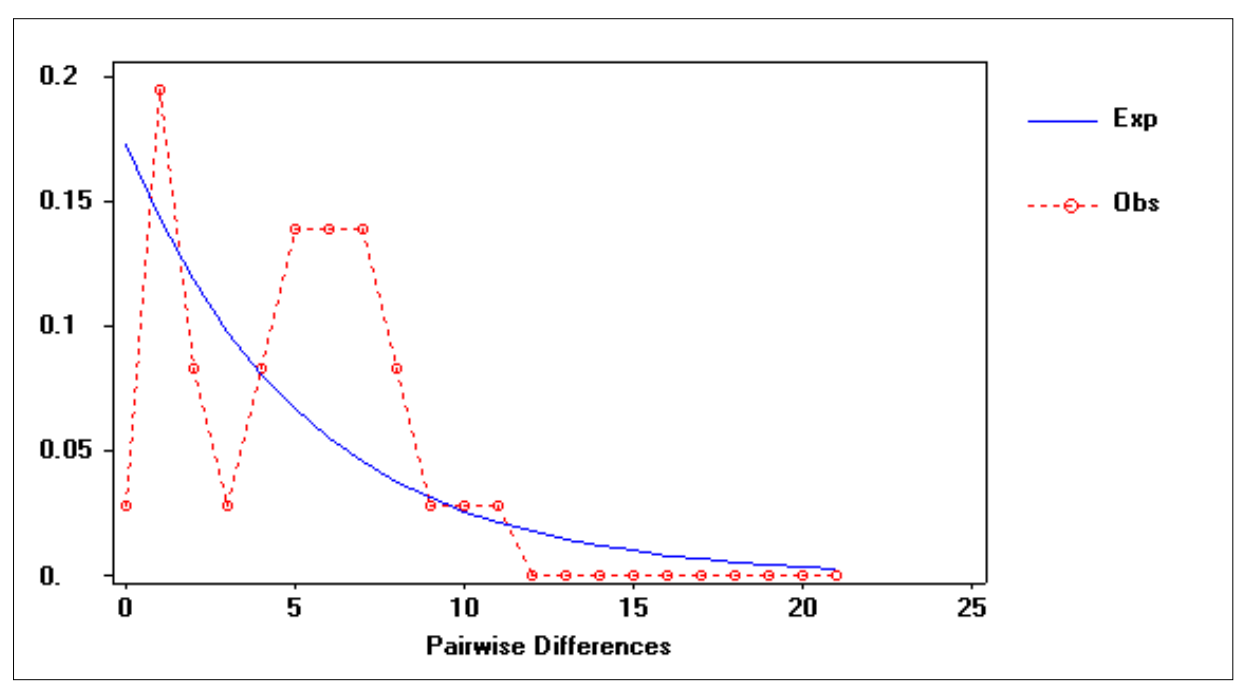

Figure 2. Bimodal pattern of mismatch analysis of S. serrata in coastal waters of Pakistan Northern Arabian Sea. 
et al., (2011): West Indian Ocean (IA), Red Sea-South China Sea (IB) West Pacific (IC) Northwest Australia (II) archived in molecular databases from the Indo Pacific region used for phylogentic analyses. Total 46 different haplotypes identified from 63 sequenced (Table 1) 99 variable sites, 84 informative sites, no insertions or deletions found. Based on the Akaike informative criterion (AIC), the best evolutionary model, the $\mathrm{T} 92+\mathrm{G}$ model selected proportion of invariable sites; base frequencies, $A=0.333, C=0.1665, G=0.1655, T=0.333$; $(A C)=0.01,(A G)=0.15,(A T)=0.02,(C G)=0.01,(C T)=$ $0.3,(G T)=0.02$. The sequence alignment of major haplotypes for S. serrata was shown in (Figure 3). The three clusters had a disjunct distribution corresponding to five geographic groups: West Indian Ocean (IA), Red Sea-South China Sea (IB) and West Pacific (IC), Northwest Australia (II), and the Northern Indian Ocean Northern Arabian Sea (III) (Figure 4). Tajima's D negative and non-significant deviation found in mutation-drift equilibrium except Western Indian Ocean (IA) (D = -
2.07591, $\mathrm{P}>0.05)$, whereas $\mathrm{Fu}^{\prime} \mathrm{s} \mathrm{F}^{\prime} \mathrm{s}$ shows similar observation ( $\left.F^{\prime} s=-12.41699, P>0.05\right)$ exception of Western Indian Ocean (IA), West Pacific (IC) and Northern Arabian Sea (III) (Table 5). The AMOVA (molecular variance analysis) intimated that phylogeographic basis for the regional partitioning of genetic structure (FST $=90.193 \%, p=0.000$ ) found in five geographic groups (Tamura and Nei distance method), within group $90.19 \%$ genetic variance, whereas among populations within groups variance $9.81 \%$ (Table 6).

\section{Discussion}

\section{Genetic Diversity and Divergence}

The current study reveals the information of genetic diversity of $S$. serrata from the coastal waters of Pakistan. It has concluded through the genetic analyses in combination with morphological characters that, the mud crab S. serrata (Forskål, 1775) is a complex of four

\footnotetext{
1. IAD_L

2. Eap

3. TAD_3

4. Iap.4

5. Iap_5

6. Tap 6

7. tap_?

9. Iap.9

10. Hap_10

11. Map_h1

12. Bap_ 12

13. Happ_t3

14. Map_ls

15. HOD_15

16. Hap_t6

17. IAD 17

18. $\mathrm{HAD}-18$

19. Hap_19

20. Hap_20

21. Hap 21

22. Hap_22

23. HAD 23

24. Hayp24

25. Iop_2s

26. Hap_26

27. Hap_27

28. Hap_28

29. Hap_25

30. Map_30

31. Has 31

32. Iap_32

33. Bab_33

34. Hap_34

35. Had_35

36. Hap_ 16

37. Iap 37

38. Hap_3a

39. Hag 39

40. Hap_40

41. Hab_41

42. Hap_42

43. Hag 43

44. Hap 44

45. Hap_45

46. Hap_46
}

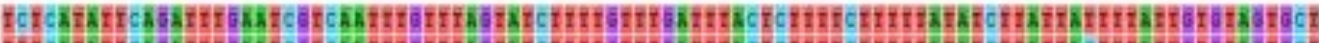

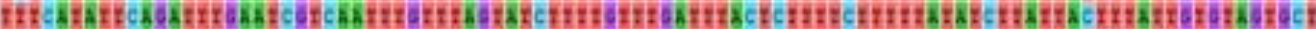

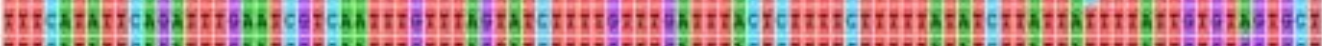

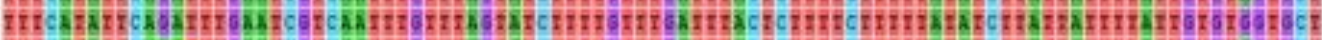

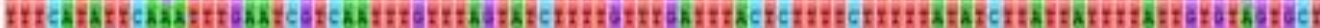

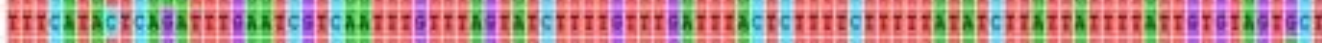

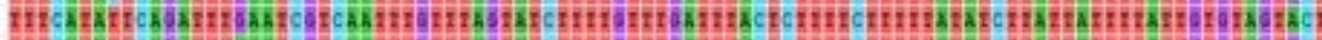

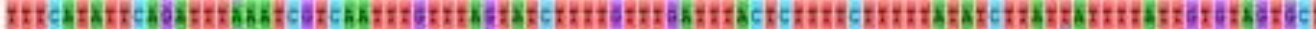

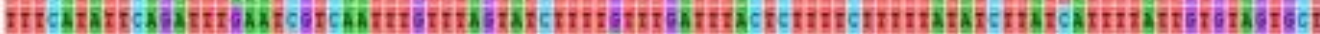

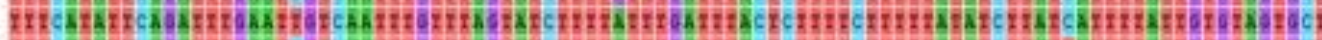

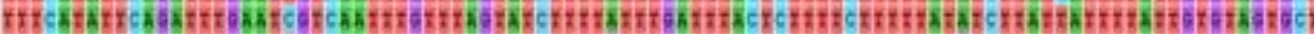

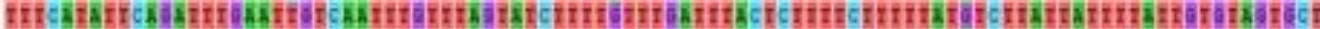

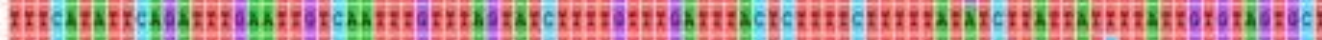

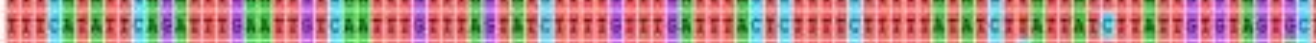

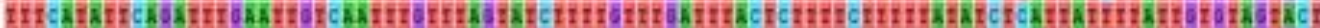

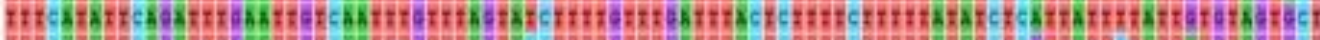

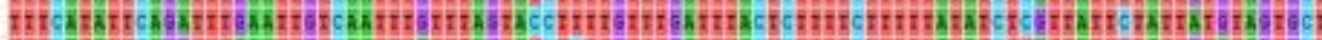

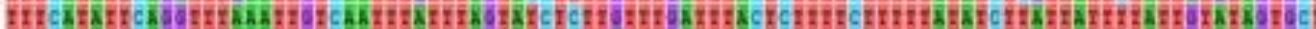

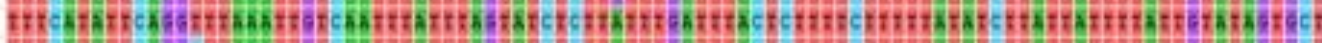

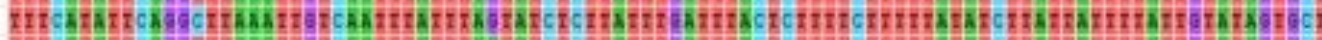

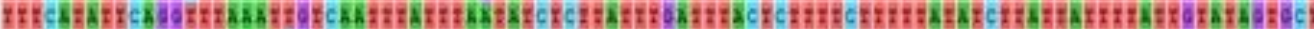

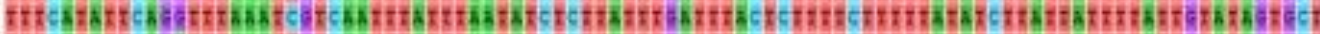

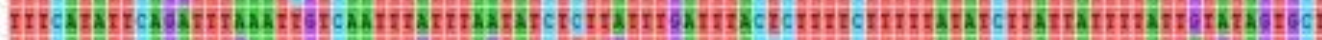

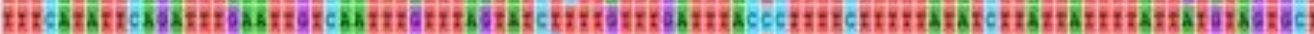

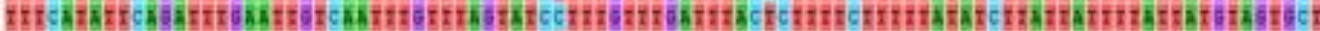

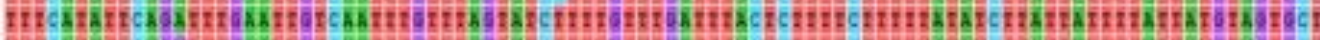

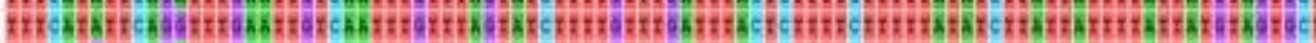

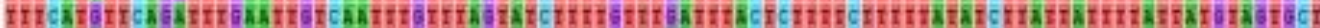

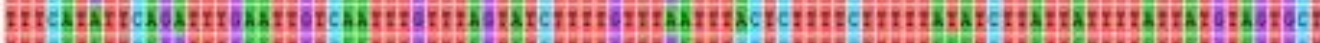

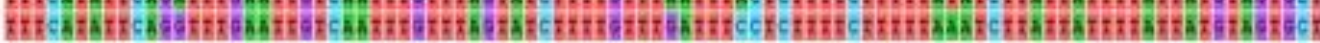

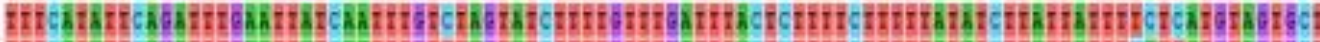

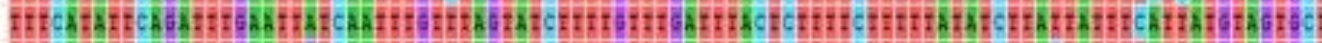

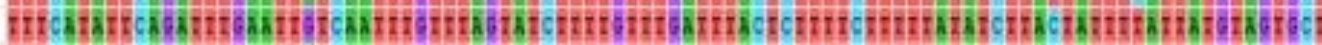

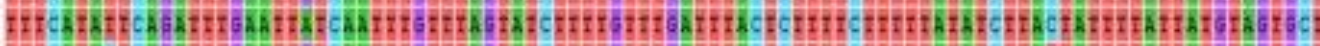

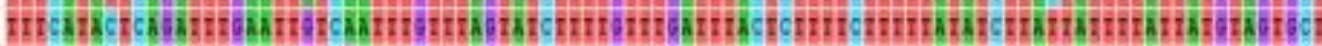

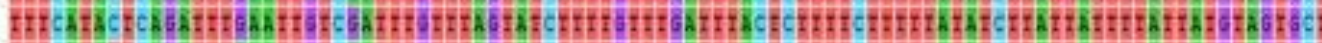

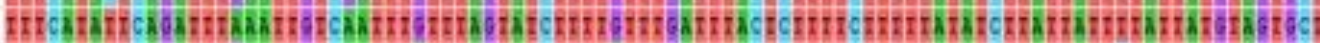

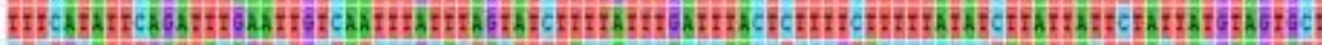

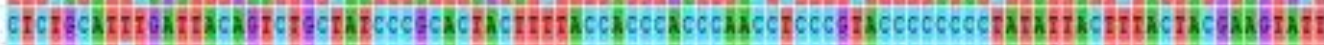

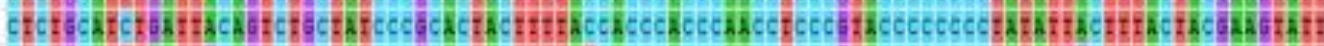

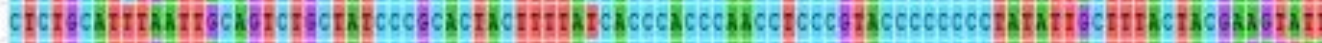

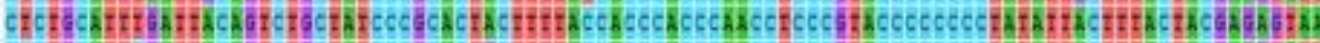

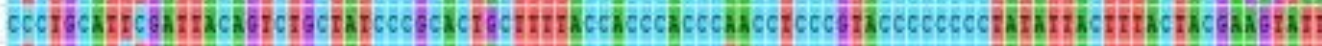

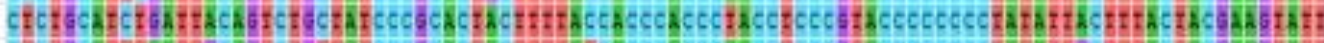

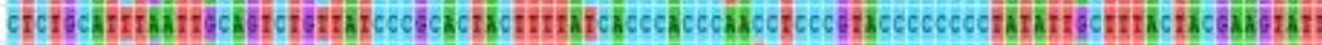

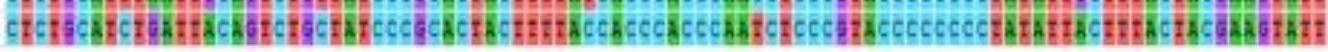

Figure 3. The sequence alignment of major haplotypes for Scylla serrata. 
species S. olivacea, S. paramamosain, S. serrata, $S$. tranquebarica (Keenan et al., 1998). The various species of Scylla already confirmed from different areas as $S$. serrata and $S$. tranquebarica through RFLP by Shekhar et al., (2005) and S. serrata, S. oceanica and S. tranquebarica through RAPD analysis by Klinbunga et al., (2000) and observed dissimilarity in genotypes among these three in eastern Thailand. Similarly, a single species of $S$. serrata reported from the coastal waters of Pakistan but now one more species $S$. olivacea conformed and included as the new report (not included in this study). The confirmation of S. olivacea indicated the range extension and disperse pattern of the species in the region. The maximum number of the haplotypes in the present study, anticipated the presence of various morphs, these differences assume the morphological variation due to their ecological and environmental responses. According to Bucklin et al., (1997); Fratini et al., (2002) and Lai et al., (2010) Portunid crab shown moderately high haplotype diversity and relatively low sequence divergence (approximately less than $0.5 \%$ ) as this trend exhibit the similarity to other marine organisms including crustacean with planktonic larvae (Gopurenko et al., 1999; Fratini et al., 2002). According to Zhou et al., (2016) genetic diversity of Sesarmid crab showed the moderate level of haplotype diversity $(0.338$ to 0.731$)$ and a low level of nucleotide diversity $(0.00058$ to 0.00278 ). Klinbunga et al., (2000) estimated genetic diversity between $S$. serrata, $S$. tranqubarica and $S$. oceanica and large genetic differences between species were found $(D(i j)=0.425$ to 0.751 ), whereas those between populations within each species were much lower $(D(i j)=0.171$ to 0.199$)$ and revealed the moderate genetic exchange between sympatric and different species rather than a single Panimitic species as exhibit different morph in eastern Thailand.

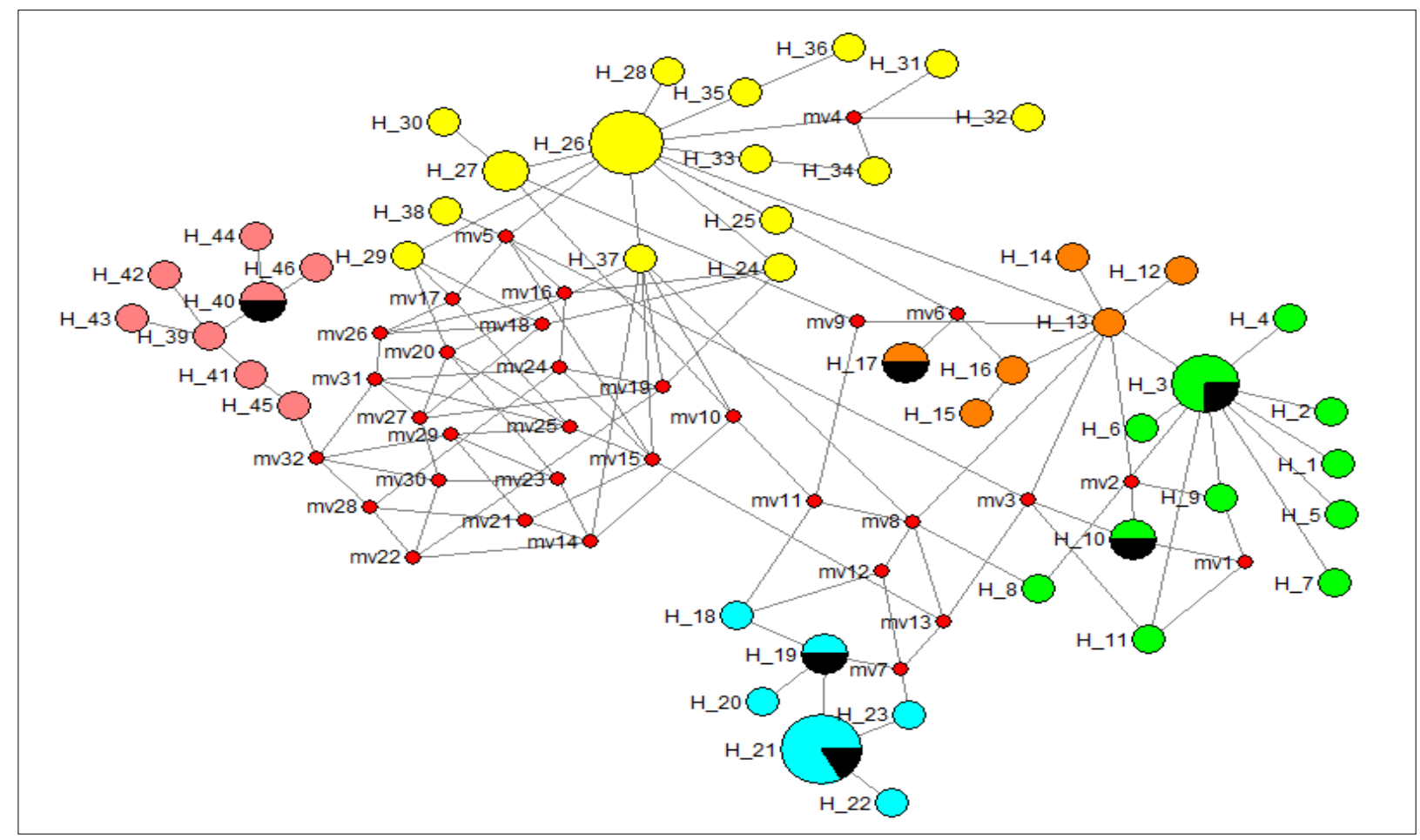

Figure 4. The phylogenetic relationship of haplotypes for Scylla serrata (clades I, II and III): MJ network and steps of over two substitutions between the haplotypes for MJ network. The distributional regions of haplotypes in networks are distinguished using different colors with dark purple for Northwest Australia, yellow from Arabian Sea, cyan for West Pacific, pink for Red Sea-South China Sea, and green for West Indian Ocean.

Table 5. Tajima's $D$ and Fu's F, SSD and Raggedness Index for COI by geographic groups of Scylla serrata

\begin{tabular}{lccccc}
\hline & $1 \mathrm{~A}$ & $1 \mathrm{~B}$ & $1 \mathrm{C}$ & 11 & 111 \\
\hline Haplotype & 20 & 7 & 15 & 12 & 9 \\
Tajima's D & -2.07591 & -0.10944 & -1.49598 & -1.12253 & -1.14965 \\
P-value & $0.002^{*}$ & 0.55300 & 0.064 & 0.188 & 0.139 \\
Fu's FS test & -12.41699 & -1.99294 & -8.55732 & -2.89747 & -1.09284 \\
P-value & $0.000^{*}$ & 0.056 & $0.000^{*}$ & $0.006^{*}$ & 0.044 \\
SSD & 0.00341 & 0.03036 & 0.03431 & 0.00909 & 0.02467 \\
P-value & 0.6200 & 0.600 & 0.1300 & 0.6300 & 0.6900 \\
Raggedness Index & 0.05620 & 0.07483 & 0.19166 & 0.10468 & 0.05633 \\
P-value & 0.4100 & 0.88 & 0.0600 & 0.5600 & 0.7300 \\
\hline
\end{tabular}


The ability to the identification of these species has numerous applications like distribution range of larvae and environmental parameters that affect the survival and growth of juveniles and hybridizing breeding studies, phylogenetic relationships and genetic identity of Scylla species from the coastal waters of Pakistan. The minimum nucleotide diversity inherent character of crustacean (Shubart et al., 2006) whereas haplotype diversity of S. serrata in tropical Africa similar to the other Indo-Pacific marine species with the planktonic larval stage (Brasher et al., 1992; Lavery et al., 1996; Palumbi et al., 1997; Williams and Benzie, 1997, 1998). Genus Scylla has shown the highest divergence rate (0.102 \pm 0.009$)$ within species. Ma et al., (2012) observed interspecific distances higher than 0.02 . Viswanathan et al., (2012) perform the analysis of mitochondrial $\mathrm{COI}$ in $\mathrm{S}$. olivacea and the observed genetic distance 0.093 between four species of Genus Scylla. According to Stephenson (1968b), previous taxonomic reviews considered these variations as meagre geographic variants, whereas (Stephenson 1972a; Fratini Vannini, (2002); Ragionieri et al., 2009) measured that this regional inconsistency may be the consequence of speciation processes suggested that the evolutionary history of speciation across the Indo-West Pacific region remain complex for genus Scyllaaccording to earlier consideration. The further detailed genetic studies helpful to resolve the genetic diversity and speciation of species in future.

\section{Demography of Scylla serrata}

Climatic and geological changes in the environment on large scales play a significant role in shaping the rates and patterns of diversification (Oaks, 2014) and also influence the evolutionary history of whole communities of co-distributed species and segregate groups or populations of an organism and cause a temporal cluster of speciation. Genetic bottlenecks (colonization events) followed by demographic expansions strengthen the contribution to genetic diversity and our results of Tajima's D test and Fu's Fs-test indicate that $S$. serrata might have undergone a rapid demographic growth. According to Lavery et al., (1996) Scylla serrata underwent a rapid demographic growth in the recent past. Traces of prehistoric demographic expansion observed in species experiencing population turn down in the present and the population structuring indicates reduced gene flow between geographically secure sites, in spite of the elevated potential for S. serrata dispersal.

\section{Phylogeography of the Scylla serrata}

The demography of the Scylla serrata revealed that the dispersal of common species throughout the Indo West Pacific (IWP) like; in the coastal areas of East Africa, India, the Indo-Malaysia archipelago, various islands and Australia. The previously phylogeographic pattern of S. serrata have been studied based on the coding mitochondrial DNA cytochrome oxidase subunit I gene (COI) (Gopurenko et al. 1999; Fratini and Vannini 2002; Gopurenko and Hughes 2002; He at al., 2011). According to species range description the Gopurenko et al., (1999) defined S. serrata population into two distinct clades, clade I, distributed across the Indo Pacific region, whereas clade II, confined to Northern Australia. A particular expansion event from a Western Pacific origin the population of $S$. serrata, colonized in the Indian Ocean during the last Pleistocene period and that infer existing gene flow between populations interrupted by a unique haplotype. Fratini et al., (2002) also describes $S$. serrata within the Indian Ocean and revealed that a significant genetic discrimination and low level of gene flow between geographically lock sites, although the elevated prospective for dispersion. Similarly, He, et al., (2011) studied the Phylogeography of the mud crab (Scylla serrata) in the Indo-West Pacific and concluded that $S$. serrata distributed in two major clades: clade one distributed widely across the entire IWP, whereas the other clade (Clade II) is confined to Western and Northern Australia and reveled the phylogeographic structure of Scylla serrate related to four subpopulations: Northwest Australia, West Indian Ocean, Red Sea-South China Sea and West Pacific. In the current study, the neutrality test (to estimate of unique mutations, as evidence of recent population expansion) showed non-significant results except West Indian Ocean (IA). Whereas Fu's F's shown significant variation in West Pacific (IC) Northern Indian Ocean Northern Arabian Sea (III), Mismatch analysis showed a bimodal distribution in Northern Indian Ocean Northern Arabian Sea, therefore consistent distribution with allopatric divergence followed by population growth. The negative distribution indicated a slight population expansion. According to Liao et al., (2010) and Rosly et al., (2013) negative non-significant value induced by the population extension and restricted to sampling sites of the crab population. In the present study different haplotypes obtained as depicted by He et al., (2011) from the gene bank and revealed the existence of four subpopulations: Northwest Australia, West Indian Ocean, Red Sea-South China Sea and West Pacific in

Table 6. AMOVA using the Tamura and Nei distance method from five subpopulations for Scylla serrata

\begin{tabular}{lcccc}
\hline Source of Variation & df & Sum of squares & Variance components & Percentage of variance \\
\hline Among populations & 4 & 557.126 & 11.33175 \\
Within population & 58 & 71.461 & 1.23209 & 90.19 \\
Total & 62 & 628.587 & 12.56384 \\
Fixation Index (FST) & & 0.90193 & & \\
\hline
\end{tabular}


addition sequences form the coastal waters of Pakistan including for the analysis and evaluate the phylogeographic pattern of $S$. serrata. The similar pattern described by He et al., (2011), clade one the IWP, Clade II Western and Northern Australia, an additional clade confined to the Pakistan northern Arabian Sea and caused by the allopatric speciation (geographic speciation, vicariant speciation). The similar speciation observed in lobster subspecies $P$. homarus megasculptus and $P$. homarusrubellus attributed to the weaker glacial surface circulation due to the summer south-west monsoon wind in the northwest Indian Ocean (Somali / Arabian basin). The Agulhas current around the southeast coast of South Africa and tip of South Madagascar weaker oceanic circulation as compared to present (Interglacial) time. LaccadiveChagos Ridge to the Southwest of the Indian continent would result in increases retention of larvae within the Northern Arabian Sea thereby promoting speciation (Pollock, 1993). This study provides insight towards the preliminary understanding of the different genetic process that regulates community assemblage and leads towards a study of evolutionary biology.

\section{Acknowledgements}

This work is supported by a Higher Education Commission (HEC) of Pakistan, through grant No EC No: $20-1673 / R$ and $D / 10$ to NUS which is gratefully acknowledged.

\section{References}

Avise, J.C. (1989). A role for molecular genetics in the recognition and conservation of endangered species. Trends in Ecology and Evolution, 4, 279-281.

Avise, J.C., Power, A.J., \&Walker, D.E. (2004). Genetic sex determination, gender identification and pseudo hermaphroditism in the knobbed whelk, Busycon carica (Mollusca: Melongenidae). Proceeding Biological Science Marine, 22, 271(1539), 641 646. http:// doi.org/10.1098/rspb.2003.2533

Ayre, D.J. \& Hughes, T.P. (2000). Genotypic diversity and gene flow in brooding and spawning corals along the Great Barrier Reef, Australia. Evolution, 54, 1590-1605

Bandelt H.J., Forster P., \&Ro"hl A. (1999). Median-joining networks for inferring intraspecific phylogenies. MolecularBiology and Evolution, 16, 37-48.

Brasher, D.J., Ovenden, J.R., \& White, R.W.G. (1992b). Mitochondrial DNA variation and phylogenetic relationships of Jasus spp. Journal of Zoology London, 227, 1-16.

Brophy, T.R. (2004). Geographic variation and systematic in the South-east Asian turtles of the genus Malayemys (Testudines: Bataguridae). Hamadryad, 29, 63-79.

Bucklin, A., Smolenack, S.B., Bentley, A.M., \& Wiebe, P.H. (1997). Gene flow patterns of the euphausiid, Meganyctiphanes norvegica, in the N Atlantic based on DNA sequences for mitochondrial cytochrome oxidase I and cytochrome b. Journal of Plankton Research, 19, 1763-1781
Chakraborty, R. (1990). Mitochondrial DNA polymorphism reveals hidden heterogeneity within some Asian populations. American Journal of Human Genetics, 47, 87-94.

Chen, J.H., Pan, D., \&Groves, C. et al., (2006). Molecular phylogeny of Nycticebus inferred from mitochondrial genes. International Journal of Primatology, 27(4), 11871200

Cristensen, S.M., Macintosh, D.J., \& Phuong, N.T. (2004). Pond production of the mud crabs Scylla paramamosian (Estampador) and Scylla olivacea (Herbst) in the Mekong Delta, Vietnam, using two different supplementary diets. Aquatic Research,35, 1013-1024.

Dai, A., \& Yang, S., (1991). Crabs of the China Seas. Beijing, China, Ocean Press. 682 pp.

David, G. (2002). Genetic Structure within the Distribution of the Indo-West Pacific Mud Crab Scylla serrata (Forskål, 1775). Thesis.

Estampador, E.P. (1949a). Studies on Scylla (Crustacea: Portunidae) I. Revision of the genus. Philippine Journal of Science, 78, (1) 95-108, plates 1-3.

Estampador, E.P. (1949b). Scylla (Crustacea: Portunidae). II. Comparative studies on spermatogenesis and oögenesis. Philippine Journal of Science, 78(3), 301-353, plates 114.

Ewens, W.J. (1972). The sampling theory of selectively neutral alleles. Theoretical Population Biology, 3, 87112.

Fabricius, J.C. (1798). Supplementum Entomologiae Systematicae. $572 \mathrm{pp}$.

Féral, J.P. (2002). How useful are the genetic markers in attempts to understand and manage marine biodiversity? Journal of experimental Marine Biology and Ecology, 268, 121- 145

Forskal, P. (1775). Descriptions animalium, avium, amphibiorum, piscium, insectorum, vermium. (Hauniae.) (Quoted from Sherborn, 1902).

Fratini, S., Vannini, M., Cannicci, S., \& Schubart, C.D. (2005). Tree-climbingmangrove crabs:a case of convergent evolution. Evolutionary Ecology Research, 7(2), 219-233.

Fratini, S., \& Vannini, M. (2002). Genetic differentiation in the mud crab Scylla serrata (Decapoda: Portunidae) within the Indian Ocean. Journal of Experimental Marine Biology and Ecology, 272,103-116.

Fuseya, R. (1998). Studies on the species identification of the genus Scylla (Ph.D Thesis). Tokyo University of Fisheries. [In Japanese]

Fuseya, R., \& Watanabe, S. (1995). Notes on the taxonomy of the genus Scylla. Cancer, 4, 5-8 [In Japanese]

Fuseya, R., \& Watanabe, S. (1996). Genetic variability in the mud crab genus Scylla (Brachyura: Portunidae). Fisheries Science, 62(5), 705-709.

Fushimi, H. (1983a). Mud crab. Proceedings of technical consulting conference for promotion of the stock enhancement program in the middle Pacific area of Japan.

FU, Y.X. (1997). Statistical tests of neutrality of mutations against population growth, hitchhiking and background selection. Genetics, 147,915-925.

Hedgecock, D. (1986). Is gene flow from pelagic larval dispersal important in the adaptation and evolution of marine invertebrates? Bulletin of Marine science, 39(2), 550564.

Herbst, J.F.W. (1782-1804). Versucheiner Naturgeschichte der Krabben und Krebsenebsteiner Systematischen 
Beschreibungihrer Verschiedenen Arten. Gottlieb August Lange, Berlin and Stralsund. 1-3, 515, 62 pls.

Hill, B.J. (1994). Offshore spawning by the portunid crab Scylla serrata (Crustacea: Decapoda). Marine Biology, 120, 379-384.

Huelsenbeck J.P., \&Ronquist F. (2001). MRBAYES: Bayesian inference of phylogeny. Bioinformatics, 17, 754-755.

Gopurenko, D., Hughes, J.M., \& Keenan, C.P. (1999). Mitochondrial DNA evidence for rapid colonisation of the Indo-West Pacific by the mud crab Scylla serrata. Marine Biology, 134, 227-233.

Gopurenko D., Hughes, J.M. \&Ma. J. (2002). Identification of polymorphic microsatellite loci in the mud crab Scylla serrata (Brachyura: Portunidae). Molecular Ecology Notes, 2, 481-483.

Jirapunpipat, K., Aungtonya, C., \& Watanabe, S. (2008). Morphological study and application of multivariate analysis for the mud crab genus Scylla in Klongngao mangrove Ranong province, Thailand. Phuket Marine Biological Center Research Bulletin, 69, 7-24

Joel, D.R. \& Raj, P.J.S. (1980). Taxonomic remarks on two species of the genus Scylla de Haan (Portunidae: Brachyura) from Pulicat Lake. Journal of the Inland Fisheries Society of India, 12(2), 39-50.

Kathirvel, M., \& Srinivasagam, S. (1992). Taxonomy of the mud crab Scylla serrata (Forskal) from India. In C. A. Angell (Ed.). The Mud Crab. Ibid. (pp. 127-132).

Kazmi, Q.B., Kazmi, M.A., \&Keenan, C.P. (2000). Species variability in the mangrove mud crab (Scylla) in Karachi Indus delta with notes on its fisheries. Pakistan journal of Fish, 1(1), 7-10.

Keenan, C.P. \& Shaklee, J.B. (1985). Electrophoretic identification of raw and cooked fish fillets and other marine products. Food Technology in Australia, 37, 117128.

Keenan, C.P., Davie, P.J.F., \& Mann, D.L. (1998). A revision of the genus Scylla De Haan, 1833 (Crustacea: Decapoda: Brachyura: Portunidae). Raffles Bulletin of Zoology, 46, 217-245.

Keenan, C.P., Mann, D.L., Lavery, S., \& Davie, P. (1995). Genetic relationship, morphological identification and taxonomy of mangrove crabs, genus Scylla, from throughout the Indo-Pacific. ACIAR Project Report, QDPI: Brisbane.

Klinbunga, S., Boonyapakdee, A., \&Pratoomchat, B. (2000). Genetic diversity and species diagnostic markers of Mud Crabs (Genus Scylla) in Eastern Thailand Determined by RAPD Analysis. Marine Biotechnology, (NY), 2(2), 180187.

Knowlton, N. (1993). Sibling species in the sea. Annual Review of Ecology and Systems, 24, 189-

Kumar, S., Stecher, G., \&Tamura, K. (2016). MEGA7: Molecular Evolutionary Genetics Analysis version 7.0 for bigger datasets. Molecular Biology and Evolution, 33, 18701874.

He, L., Zhang, A., Zhu, C., Weese, D., \&Qiao, Z. (2010). Phytogeography of the mud crab (Scylla serrata) in the Indo-West Pacific reappraised from mitochondrial molecular and oceanographic clues: transoceanic dispersal and coastal sequential colonization. Molecular Ecology, 32(1), 52-64.

Lai, J.C.Y., Ng, P.K.L., \& Davie, P.J.F. (2010). A revision of the Portunus pelagicus (Linnaeus, 1758) species complex (Crustacea: Brachyura: Portunidae), with the recognition of four species. The Raffles Bulletin of Zoology,58(2), 199-237.
Lavery, S., Moritz, C. \& Fielder, D.R. (1996). Indo-Pacific population structure and evolutionary history of the coconut crab Birgus latro. Molecular Ecology, 5, 557-570

Liao, P.C., Kuo, D.C., Lin, C.C., Ho, K.C., Lin, T.P., \& Hwang, S.Y. (2010). Historical spatial range expansion and a very recent bottleneck of Cinnamomum kanehirae Hay. (Lauraceae) in Taiwan inferred from nuclear genes. BMC Evolutionary Biology, 10, 124.

Librado, P. \& Rozas, J. (2009). DnaSP v5: A software for comprehensive analysis of DNA polymorphism data. Bioinformatics, 25, 1451-1452. http:// doi.org/ 10.1093/bioinformatics/btp187.

Ma, H. Ma, C. \& Ma, L. (2012). Molecular identification of genus Scylla (Decapoda: Portunidae) based on DNA barcoding and polymerase chain reaction. Biochemical Systematics and Ecology, 41, 41-47

Mantelatto, F., Robles, R., Schubart, C.D., \& Felder, D.L. (2009). Molecular Phylogeny of the Genus Cronius Stimpson, 1860, with 567 Reassignment of $C$. tumidulus and Several American Species ol' Port un us to the Genus Achelous De Haan, 1833 (Brachyura: Portunidae). Decapod crustacean phylogenetics / (Eds), W.J. Martin., A.K. Crandall., \& D.F. Folder., p. cm. (Crustacean issues) bibliographical references and index. ISBN 978-1-42009258-5 (hardcover: alk. paper) 1. Decapoda (Crustacea) 2. Phylogeny. I. Martin, Joel W. II. Crandall, Keith A. III. Felder, Darryl F. IV. Title. V. Series. QI.444.iM33D44 2009

Matsuoka, N., \&Hatanaka, T. (1991). Molecular evidence for the existence of four sibling species within the sea urchin, Echinometra mathaei in Japanese waters and their evolutionary relationships. Zoological Science, 8, 121-133.

Nei, M. (1987). Molecular evolutionary genetics. Columbia University press.

Oaks, J.R. (2014). An improved approximate-Bayesian modelchoice method for estimating shared evolutionary history. BMC Evolutionary Biology, 14,150.

Ong, K.S. (1964). The early developmental stages of Scylla serrata Forskal (Crustacea, Portunidae), reared in the laboratory. Proceeding of Indo-Pacific Fisheries Council. 11, 135-146.

Oshiro, N. (1988). Mangrove crabs (Scylla spp) S. Syokita (Ed.), Aquaculture in tropical areas (198-209 pp). Midorishobo, Tokyo, [In Japanese]., $11 \mathrm{pp}$

Palumbi, S.R., Martin, A., Romano, S., McMillan, W.O., Stice, L., \& Grabowski, G. (1991). The Simple Fool's Guide to PCR, Version 2. University of Hawaii Zoology Department, Honolulu.

Pollock, D.E. (1993). Speciation in spiny lobsters-clues, climatically induced changes in ocean circulation patterns. Bulletin of Marine Science, 53(3), 937-944.

Pollock, D.E.; Cockcroft, A.C.; Groeneveld, J.C.; Schoeman, D.S. (2000): The commercial fisheries for Jasus and Palinurus species in the south east Atlantic and South-west Indian Ocean. InB.F. Phillips \& J. Kittaka (Eds.), Spiny lobsters, Fisheries and Culture

Chapter 5, (105-120 pp). 125pp.

Polzin, Tobias \& Vahdati Daneshmand, Siavash. (2003). On Steiner Trees and Minimum Spanning Trees in Hypergraphs. Operations Research Letters, 31, 12-20. http:// doi.org10.1016/S0167-6377 (02)00185-2.

Pozzoli, U., Menozzi, G., Fumagalli, M., Cereda, M., Comi,G.P., Cagliani, R., Bresolin, N., \& Sironi, M.( 2008). Both selective and neutral processes drive GC content 
evolution in the human genome. BMC Evolutionary Biology, 8, 99. http:// doi.org/10.1186/1471-2148-v8-99

Radhakrishnan, C., \& Samuel, C.T. (1982). Report on the occurrence of one subspecies of Scylla serrata (Forskål) in Cochin backwater. Fisheries Technology, 19, 5-7.

Ragionieri, L. Fratini, S. Vannini, M. Schubart, C. (2009). Phylogenetic and morphometric

differentiation reveal geographic radiation and pseudo-cryptic speciation in a mangrove crab from the Indo-West Pacific. Molecular Phylogenetics and Evolution.52, DO 10.1016/j.ympev.2009.04.008.

Rogers, A.R. (1995). Genetic evidence for a Pleistocene population explosion. Evolution,49, 608-615.

Ronquist F., \&Huelsenbeck J.P. (2003) MRBAYES 3: Bayesianphylogenetic inference under mixed models. Bioinformatics, 19, 1572-1574.

Rosly M.H.A., Nor, M.S.A., Yahya, K., \& Naim, D.M. 2013. Mitochondrial DNA diversity of mud crab Scylla olivacea (Portunidae) in Peninsular Malaysia: a preliminary assessment. Molecular Biology Reports. 40, 6407-6418.

Rosly, H. A., Nor, S. A., Yahya, K., \&Naim, D. M. (2013). Mitochondrial DNA diversity of mud crab Scylla olivacea portunide) in peninsular Malaysia: a preliminary assessment. Molecular Biology Review, 40, 6407-6418.

Sakai, T. (1976). Crabs of Japan and Adjacent Seas. Kodansha Ltd.

Fratini, S. Vannini, M. (2002), Genetic differentiation in the mud crab Scylla serrata (Decapoda: Portunidae) within the Indian Ocean. Journal of Experimental Marine Biology and Ecology, 272. DO - 10.1016/S00220981(02)00052-7.

Schubart, C.D., Neigel, J.E., \& Felder, D.L. (2000b). Use of the mitochondrial 16S rRNA gene for phylogenetic and population studies of Crustacea. Crustacean Issues, 12, 817-830.

Schwarz, G., 1978. Estimating the Dimension of a Model. The Annals of Statistics, 6(2), 461-464. Institute of Mathematical Statistics Stable. http://www.jstor.org/stable/2958889 Accessed: 16/09/2008 10:46

Schubart, C.D., Cannicci, S., Vannini, M., \& Fratini, S. (2006). Molecular phylogeny of grapsoid crabs (Decapoda, Brachyura) and allies based on two mitochondrial genes and a proposal for refraining from current superfamily classification. Journal of Zoological Systematics and Evolutionary Research, 44(3), 193-199. http://www.DOI:10.1111/j.1439-0469.2006.00354.x

Serene, R. (1952). Les especes du genere Scylla a Nhatrang (Vietnam). Proceedings of Indo-Pacific Fisheries Council, 3(2), 133-137

Kenneth Sherman, Ezekiel N. Okemwa, \& Micheni J. Ntiba. (2009). Large Marine Ecosystems of the Indian Ocean: Assessment, Sustainability and Management. John Wiley \& Sons, Science., 416 pp.

Shekhar, M.S., Gopikrishna, G., \& Azad, I.S. (2005). PCR-RFLP Analysis of $12 \mathrm{~s}$ and $16 \mathrm{~s}$ mitochondrial rRNA genes from brackish water finfish and shellfish species. Asian Fisheries Science, 18, 39-48 Asian Fisheries Society, Manila, Philippines $39 \mathrm{pp}$.

Shekhar, M.S., Natarajan, M., \& Kumar, V. (2011). PCR-RFLP Analysis of $12 \mathrm{~S}$ and 16SMitochondrial rRNA Genes of Grey mullets from East coast of India. Indian journal of Geo Marine Sciences, 40(4) 529-534.
Stephenson, W., (1972). An annotated checklist and key to the Indo-West-Pacific swimming

Crabs (Portunidae). Royal Society New Zeeland Bulletin, 10, 164

Stephenson, W., (1968b). Studies onPortunus pelagicus (Linnaeus) andP. sanguinolentus (Herbst). Occasional Papers of the Bernice P. Bishop Museum, 23(15), 385399, figs 1-3.

Stiassny, M.L.J. (1993). What are grey mullets? Bulletin of Marine Science, 52, 197- 219

Stephenson, W., and Campbell, B. (1960). The Australian portunids (Crustacea: Portunidae) IV. Remaining genera. Australian Journal of Marine and Freshwater Research, $11,73-122$.

Tajima, F. (1989). Statistical methods to test for nucleotide mutation hypothesis by DNA polymorphism. Genetics, 123, 585-595.

Tamura, K. \& Nei M. (1993). Estimation of the number of nucleotide substitutions in the control region of mitochondrial DNA in humans and chimpanzees. Molecular Biology and Evolution. 10, 512-526.

Thompson, J., Gibson, T.F., Plewniak, Jeanmougin, F., \& Higgins, D. (1997). The CLUSTAL_X windows interface: flexible strategies for multiple sequence alignment aided by quality analysis tools. Nucleic Acids Research, 22, 4876-4882.

Viswanathan, C., Elumalai, V., Pravinkumar, M., \& Raffi, S.M. (2012). DNA Barcoding and First report on the confirmation of mud crab Scylla olivacea (Brachyura: Portunidae) availability in East coast of India. Journal of Applied Environmental and Biological Sciences, 1(1), 1-4.

Watterson, G. A. (1975). On the number of segregating sites in genetical models without recombination. TheoreticalPopulation Biology, 7, 256-276

Watanabe, S. and Fuseya, R. (1997). Notes on the identification of the species in genus Scylla. Cancer, 6, 33-36.

Williams, S. T., \& Benzie, J.A.H. (1998). Evidence of a biogeographic break between populations of a high dispersal starfish: Congruent regions within the IndoWest Pacific defined by Colour morphs, mtDNA and allozyme data. Evolution, 52, 87-99.

Williams, S.T., \&Benzie, J.A.H. (1997). Indo-West Pacific patterns of genetic differentiation in the high dispersal starfishLinckia laevigata. Molecular Ecology, 6, 559-573.

Wuitschick, J.D., \& Karrer, K.M., (1999). Analysis of genomic G $+C$ content, codon usage, initiator codon context and translation termination sites in Tetrahymena thermophila. J. Eukaryotic Microbiology, 46, 239-247.

Zhang S, Li X, Cui Z, Wang H, Wang C, \&Liu, X (2008). The application of mitochondrial DNA in phylogeny reconstruction and species identification of Portunid crab. Marine Science, 32, 9-18.

Zheng, Z., Scott, S., Lukas, W., \& Webb, M. (2000). A greedy algorithm for aligning DNA sequences, Journal of Computational Biology,7(1-2), 203-14.

Zhou, H., Xu, J., Yang, M., Wu, B., Yan, B., \& Xiong, Y. (2016). Population genetic diversity of Sesarmid crab (Perisesarma bidens) in China based on mitochondrial DNA. Mitochondrial DNA Part A, 27(5), 3255-3262. UK Ltd.http:// doi.org/10.3109/19401736.2015.1015002. 